\title{
Etiological Agents and Antimicrobial Susceptibility in Hospitalized Children with Acute Pyelonephritis
}

\author{
Agentes Etiológicos e Suscetibilidade aos Antimicrobianos em Crianças \\ Internadas por Pielonefrite Aguda
}

Filipa FLOR-DE-LIMA ${ }^{1,3}$, Tânia MARTINS ${ }^{1,3}$, Ana TEIXEIRA $^{1,3}$, Helena PINTO ${ }^{1,3}$, Edgar BOTELHO-MONIZ2 Alberto CALDAS-AFONSO 1,3

Acta Med Port 2015 Jan-Feb;28(1):15-20

\section{ABSTRACT}

Introduction: Antibiotic resistance driven by antibiotic use remains a major public health and professional concern. Our aim was to know the local prevalence of uropathogens and their antimicrobial susceptibility profile in acute pyelonephritis.

Material and Methods: A prospective study of patients admitted in a level III Pediatric Department ward with acute pyelonephritis from 1994 to 2012 was performed in Northern Portugal. Etiological agents and their antimicrobial sensitivity profile were evaluated in four timed periods (G1: 1994-97; G2: 2002; G3: 2007; G4: 2012).

Results: We evaluated 581 patients, $66 \%$ female with median age 22 months. Escherichia coli was the leading uropathogen and its prevalence remained stable during the last 18 years. It showed an increased sensitivity to amoxicillin-clavulanate from $71 \%$ in $\mathrm{G} 1$ to $81.5 \%$ in G4 $(p=0.001)$ and a decreased resistance rate from $8.7 \%$ in $\mathrm{G} 1$ to $2.8 \%$ in $\mathrm{G} 4(p=0.008)$. Its sensitivity to 2 nd and 3 rd generation cephalosporin was more than $90 \%(p=n s)$ and more than $95 \%$ to nitrofurantoin $(p=n s)$. Resistance rate of cotrimoxazole increased from $22 \%$ to $26 \%(p=0.008)$.

Discussion: Escherichia coli remains the main uropathogen responsible for acute pyelonephritis, reason why its antimicrobial sensitivity profile will determine the empirical therapeutic choice.

Conclusions: Amoxicillin-clavulanate remains a good first-line choice for empirical treatment of acute pyelonephritis in our inpatient health care.

Keywords: Anti-Bacterial Agents; Child; Drug Resistance, Bacterial; Pyelonephritis.

\section{RESUMO}

Introdução: A resistência aos antimicrobianos, provocada pela utilização de antibióticos continua a ser um importante problema de saúde pública e uma preocupação para os profissionais de saúde. O nosso objetivo foi conhecer a prevalência local dos uropatógenos e o seu perfil de suscetibilidade aos antimicrobiannos na pielonefrite aguda.

Material e Métodos: Estudo prospetivo nas crianças internadas por pielonefrite aguda no internamento de Pediatria de um hospital do norte de Portugal entre 1994-2012. Os agentes etiológicos e o seu perfil de sensibilidade aos antimicrobianos foram avaliados em quatro períodos de tempo (G1: 1994-1997, G2: 2002; G3: 2007; G4: 2012).

Resultados: Avaliámos 581 doentes, $66 \%$ do sexo feminino, com idade mediana de 22 meses. A Escherichia coli foi o principal uropatógeno e a sua prevalência manteve-se estável durante os últimos 18 anos. Verificou-se um aumento da sensibilidade à amoxicilina/ácido clavulânico de $71 \%$ no G1 para $81,5 \%$ no G4 $(p=0,001)$ e uma diminuição da taxa de resistência de $8,7 \%$ no $\mathrm{G} 1$ para $2,8 \%$ G4 $(p=0,008)$. A sua sensibilidade às cefalosporinas de segunda e terceira geração e nitrofurantoína foi superior a $90 \%$ $(p=n s)$. A taxa de resistência ao cotrimoxazol aumentou de $22 \%$ para $26 \%(p=0,008)$.

Discussão: A Escherichia coli continua a ser o uropatogénio mais frequente responsável por pielonefrite aguda, motivo pelo qual o seu perfil de sensibilidade aos antimicrobianos determina a escolha da antibioticoterapia empírica.

Conclusões: A amoxicilina/ácido clavulânico mantém-se como escolha de primeira linha para o tratamento empírico da pielonefrite aguda em regime de internamento.

Palavras-Chave: Pielonefrite; Antibacterianos; Crianças; Farmacorresistência Bacteriana.

\section{INTRODUCTION}

Urinary tract infection (UTI), including cystitis and pyelonephritis, remains one of the most common bacterial infection in childhood ${ }^{1}$ and its cumulative incidence in children by 6 years of age is $3-7 \%$ in girls and $1-2 \%$ in boys. ${ }^{2}$ It can be associated with long-term renal scarring, which may cause hypertension, proteinuria, pregnancyrelated complications, or even progressive renal failure..$^{2-4}$ Antibiotic resistance and multi-drug resistant infection, driven by antibiotic use, remain a major public health and professional concern. ${ }^{5}$ Annual losses stemming from

antimicrobial resistance are estimated to range from 21000 million to 34000 million dollars in the United States of America $^{6}$ and about 1500 million euros in Europe. ${ }^{7}$ Due to geographic variation of uropathogens, their mechanisms of resistance and recent changes in antimicrobial resistance, it is crucial to know the prevalence of local microbial agents and their antimicrobial susceptibility profile to adjust the initial empirical treatment of UTI. ${ }^{3-4}$ During the last decades there is concern in treating acute pyelonephritis (APN) at lowest cost and with maximum effectiveness. The aim

\footnotetext{
1. Unit of Pediatric Nephrology. Hospital Pediátrico Integrado. Centro Hospitalar de São João. Porto. Portugal.

2. Department of Clinical Pathology. Centro Hospitalar de São João. Porto. Portugal.

3. Faculty of Medicine. University of Porto. Porto. Portugal.

Recebido: 03 de Dezembro de 2013 - Aceite: 17 de Março de 2014 | Copyright @ Ordem dos Médicos 2015
} 
of this study was to evaluate the etiological agents and antimicrobial susceptibility profile of urinary pathogens in hospitalized children with APN in our center.

\section{MATERIAL AND METHODS}

A prospective study from 1994 to 2012 was performed. All children with more than 29 days of life and adolescents admitted in level III Pediatric Department ward in Northern Portugal with the diagnosis of APN were included. Until 2010 the maximum age allowed at admission was 16 years-old and less than 18 years thereafter, when National Policies changed in Pediatric Health Care. Demographic and clinical data were recorded and etiological agents and their antimicrobial sensitivity profile were evaluated in four timed periods during the last 18 years (G1: 1994-1997; G2: 2002; G3: 2007; G4: 2012). Non-selective differential media (C.L.E.D., bioMérieux, Marcy l'Etoile, France) and selective differential media (MacConkey Agar, bioMérieux, Marcy l'Etoile, France) were used in the urine samples. Another non-selective media (Blood Agar, bioMérieux, Marcy l'Etoile, France) was used when a subculture was needed. Identification and susceptibility were determined using the Vitek1 system between 1994 and 2004 and the Vitek2 system between 2005 and 2012 (both from bioMérieux, Marcy l'Etoile, France). Therapeutic protocols used during the study period were the same, and regular updates were performed according to the 'state of the art'. The study was approved by the institutional research ethics board.

Analyzed data included demographic (age and gender), clinical (known nephro-urologic malformation, previous urinary tract infection, current antibiotic prophylaxis) and microbial data (etiological agent, antimicrobial susceptibility). Diagnosis and management of APN were performed according to the protocol, in use since 1994. The criteria to hospitalization and intravenous empirical antibiotic therapy are summarized in Table 1. Antibiotic therapy was replaced according to the clinical evolution and the results of previous antibiograms were taken into account in those cases of recurrent APN due to atypical agents. Antimicrobial therapeutic failure was considered in those cases with persistent fever or positive bacteriological urine examination at 48-72 hours of therapy. ${ }^{8}$

Statistical analysis was performed by SPSS ${ }^{\circledR}$ (IBM, USA) program v.20. Continuous variables were characterized by mean ( \pm standard deviation) and median (mediummaximum) if they had symmetric or asymmetric distribution, respectively. Categorical variable were characterized by absolute and relative frequencies. To compare continuous variables with asymmetric distribution we used KruskalWallis test and to compare categorical variables we used Chi-Squared and Fisher's exact test. $P$ value less than 0.05 was considered statistically significant.

\section{RESULTS}

During the last 18 years, 581 patients were evaluated. There was prevalence of female children along the period study in all groups $(p<0.0001)$ with progressive decrease of median age at admission $(p<0.0001)$. There was an increase of nephro-urologic malformations and in the prevalence of first episode of APN in G3 and G4 $(p<0.0001)$. There were no differences in the prevalence of APN under prophylaxis and cases of antibiotic failure. Demographic and clinical characteristics are summarized in table 2.

Escherichia coli was the leading uropathogen and its prevalence remained stable during the last 18 years. There was significant decrease in the prevalence of Klebsiella spp. $(p=0.001)$ and Enterococcus spp. $(p=0.046)$ during the period study. Uropathogens causing APN during the last 18 years are summarized in Fig. 1.

Table 1 - Hospitalization criteria and empirical antibiotic therapy according to the National Protocol ${ }^{8}$

\title{
Hospitalization criteria
}

\author{
Age $\leq 3$ months \\ Poor clinical conditions: dehydration, bad perfusion, sepsis \\ Oral intolerance \\ Bad social conditions or difficulties to maintain follow-up \\ Impossibility of re-evaluation in 48-72 hours \\ Lack of response and/or clinical worsening in children under oral antibiotic \\ Recurrent acute pyelonephritis due to atypical agents \\ Nephro-urologic malformation with renal failure
}

Intravenous empirical antibiotic therapy

From $1^{\text {st }}$ to $3^{\text {rd }}$ month of life

Cefotaxime $^{*} 75-100 \mathrm{mg} / \mathrm{kg} /$ day, q8/8h OR

Ceftriaxone* $50-75 \mathrm{mg} / \mathrm{kg} /$ day, q24/24h

*Add ampicilin $100 \mathrm{mg} / \mathrm{kg} / \mathrm{day}, \mathrm{q} 6 / 6 \mathrm{~h}$ if there is clinical and analytical suspicion of sepsis 
Table 2 - Demographic and clinical characteristics of hospitalized children with APN $(n=581)$

\begin{tabular}{|c|c|c|c|c|c|}
\hline & $\begin{array}{c}\text { G124 } \\
(n=196)\end{array}$ & $\begin{array}{c}\mathbf{G 2}^{25} \\
(n=119)\end{array}$ & $\begin{array}{c}\text { G3 } \\
(n=141)\end{array}$ & $\begin{array}{c}\text { G4 } \\
(n=125)\end{array}$ & $p$ \\
\hline \multicolumn{6}{|l|}{ Gender, n (\%) } \\
\hline Female & $147(75)$ & $68(57.1)$ & $99(70.2)$ & $68(54.4)$ & \\
\hline Male & $49(25)$ & $51(42.9)$ & $42(29.8)$ & $57(45.6)$ & $<0.0001^{*}$ \\
\hline Median age, months (min-max) & $\begin{array}{c}42.6 \\
\text { (29 days- } \\
13 \text { years) }\end{array}$ & $\begin{array}{c}15.1 \\
\text { (29 days- } \\
13 \text { years) }\end{array}$ & $\begin{array}{c}19.4 \\
\text { (3 months- } \\
13 \text { years) }\end{array}$ & $\begin{array}{c}7 \\
\text { (1 month- } \\
17 \text { years) }\end{array}$ & $<0.0001^{*}$ \\
\hline Nephro-urologic malformation, $n$ (\%) & $16(8.2)$ & - & $82(58.2)$ & $71(56.8)$ & $<0.0001^{*}$ \\
\hline First APN episode, n (\%) & $107(54.6)$ & - & $121(85.6)$ & $100(80.0)$ & $<0.0001^{*}$ \\
\hline APN under prophylaxis, $n$ (\%) & - & $20(16.8)$ & $16(11.3)$ & $18(14.4)$ & $\mathrm{ns}^{*}$ \\
\hline Empirical therapeutic failure, $\mathrm{n}(\%)$ & $8(4.1)$ & $3(2.5)$ & $5(3.5)$ & $4(3.2)$ & $\mathrm{ns}^{*}$ \\
\hline
\end{tabular}

${ }^{*}$ Chi-square test, ${ }^{*}$ Kruskal-Wallis test, APN - acute pyelonephritis, ns - non significant.

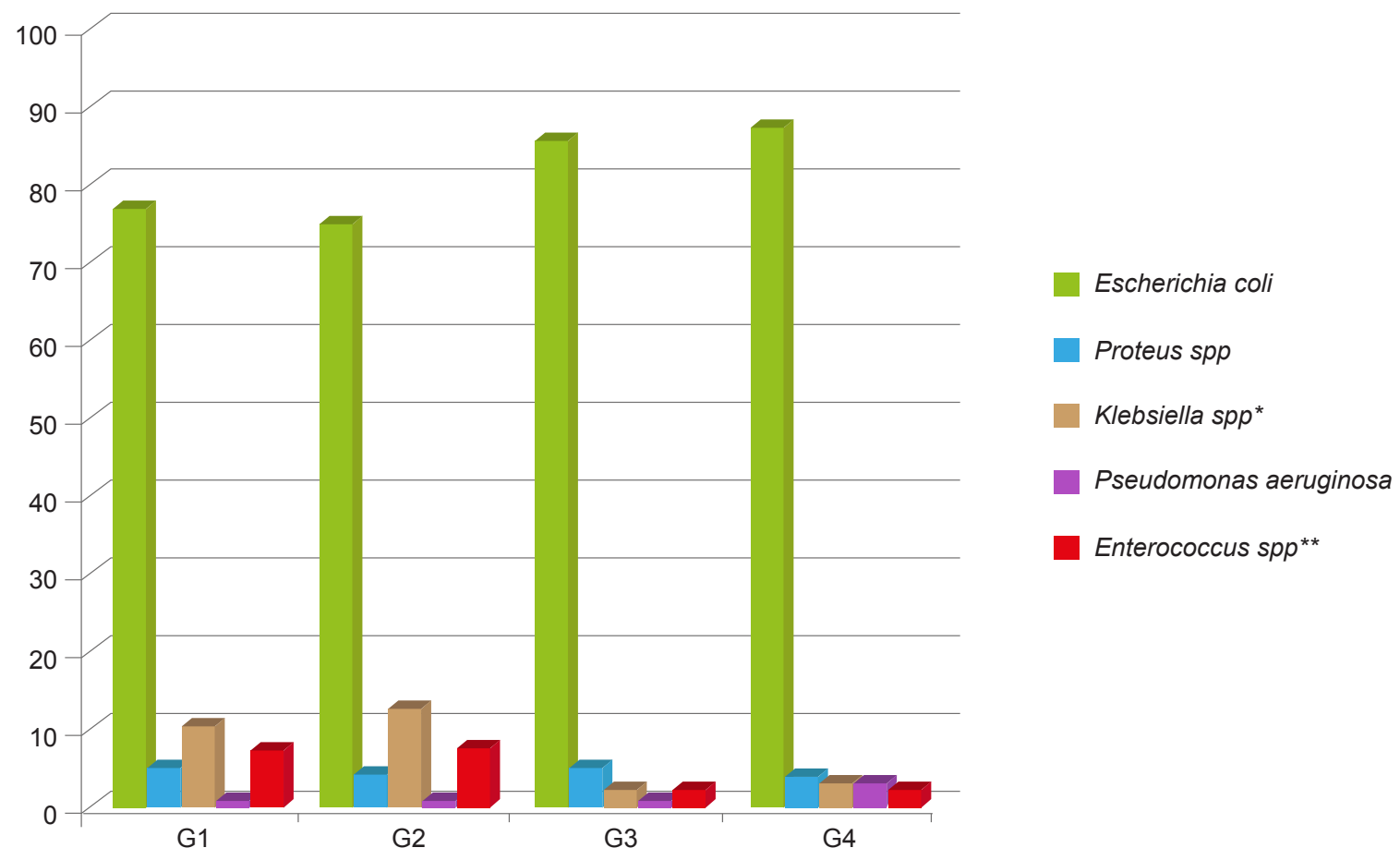

Figure 1 - Uropathogens causing APN in hospitalized children during the last 18 years.

$p=0.001$ (Fisher's exact test); ${ }^{* *} p=0.046$ (Fisher's exact test)

Escherichia coli showed an increased sensitivity to amoxicillin-clavulanate over the years from $71 \%$ in $\mathrm{G} 1$ to $81.5 \%$ in $\mathrm{G} 4$ ( $p=0.001)$, an increased intermediate sensitivity from $16 \%$ in $\mathrm{G} 2$ to $20 \%$ in G4 ( $p=0.002)$, and a decreased resistance rate from $8.7 \%$ in $\mathrm{G} 1$ to $2.8 \%$ in $\mathrm{G} 4$ ( $p=0.008)$. Its sensitivity to $2^{\text {nd }}$ and $3^{\text {rd }}$ generation cephalosporin was more than $90 \%$ ( $p=\mathrm{ns}$ ) and more than $95 \%$ to nitrofurantoin ( $p=n s$ ) over the study period. Regarding cotrimoxazole, its sensitivity decreased from $90 \%$ in $\mathrm{G} 1$ to $74 \%$ in $\mathrm{G} 4$ ( $p<$ $0.0001)$ with resistance rate from $22 \%$ to $26 \%(p=0.008)$.

The sensitivity of Proteus spp. to amoxicillin-clavulanate was $50 \%$ in $\mathrm{G} 1,100 \%$ in $\mathrm{G} 2$ and $\mathrm{G} 3$ and $67 \%$ in G4 $(p=0.008)$. There were no resistant cases to amoxicillin- clavulanate during the study period.

The sensitivity of Klebsiella spp. to amoxicillinclavulanate was $67 \%$ in $\mathrm{G} 1,56 \%$ in $\mathrm{G} 2$ and $100 \%$ in $\mathrm{G} 3$ and $\mathrm{G} 4(p=\mathrm{ns})$. The resistance rate to amoxicillin-clavulanate was $17 \%$ in $\mathrm{G} 1$ and any resistant case was registered in G2-4. Antimicrobial susceptibility profile of the most frequent uropathogens in APN is summarized in Fig.s 2-4.

\section{DISCUSSION}

Escherichia coli is responsible for $60-90 \%$ of communityacquired UTIs in childhood. .,2,4 Other common gram negative organisms include Klebsiella, Proteus, Enterobacter, and occasionally Pseudomonas. Fungal infections are much 
less common and are usually to those who are immunecompromised or diabetic, are on long-term antibiotics, or have long-term indwelling catheter. ${ }^{2}$

Escherichia coli remains the main uropathogen responsible for APN, reason why it antimicrobial sensitivity profile will determine the empirical therapeutic choice. In Portuguese pediatric population, Escherichia coli is the main etiological agent with variable prevalence according to the different centers $(53-81 \%)$. Its resistance to ampicillin is $44.8-54.9 \%, 5.7-21.7 \%$ to amoxicillin-clavulanate, $1.2-$ $4 \%$ to cephuroxim, $1-4.7 \%$ to nitrofurantoin and $19-31.3 \%$ to cotrimoxazole. ${ }^{8}$ There is high rates of resistance of this agent to cotrimoxazole, already described in other studies 3,9 probably as consequence of indiscriminate use of this drug in the past. Uropathogens other than Escherichia coli were more prevalent in children and adolescents with uropathy and there were no differences between those under prophylaxis.

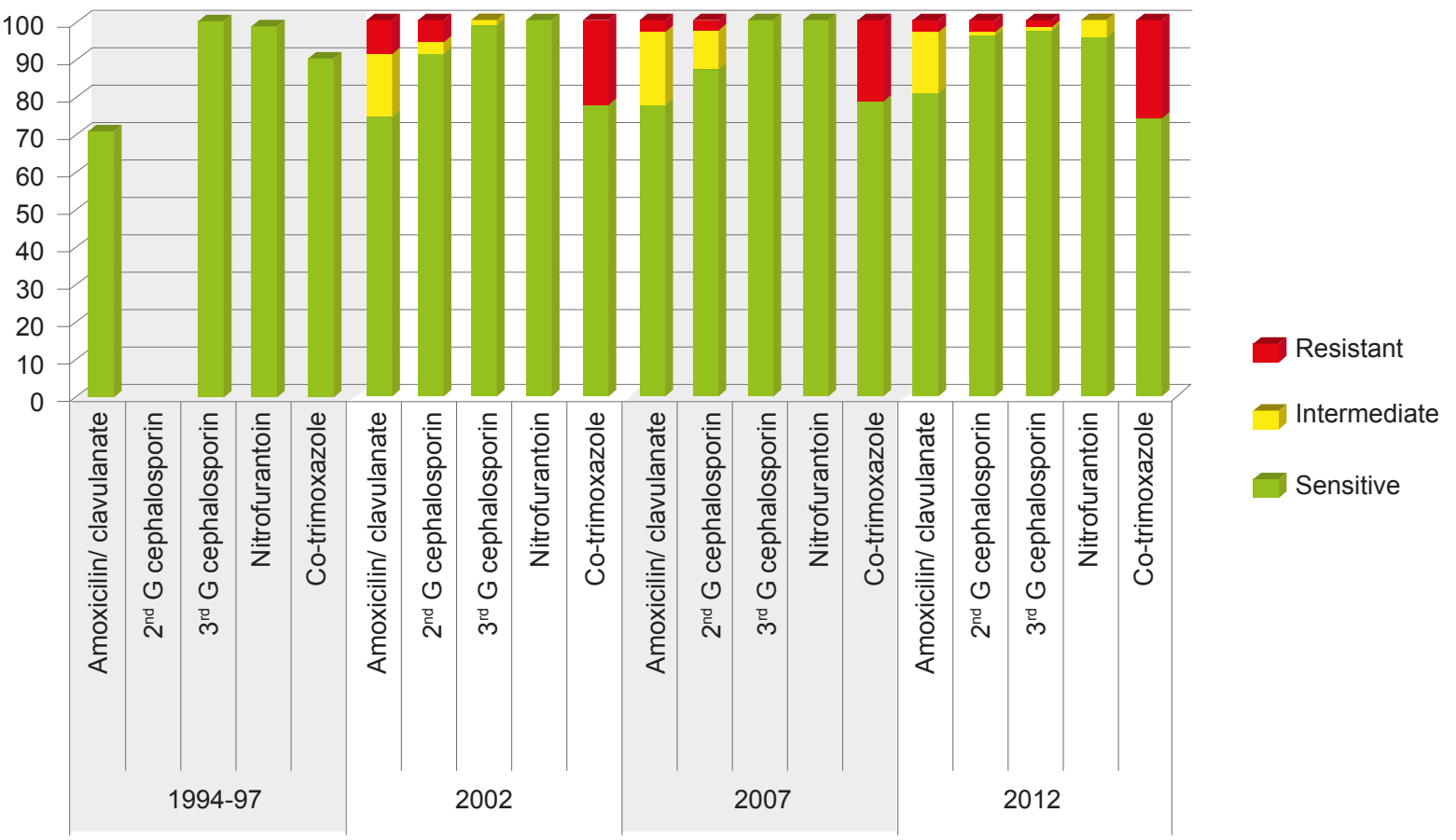

Figure 2 - In vitro antimicrobial susceptibility of Escherichia coli causing APN in hospitalized children



Figure 3 - In vitro antimicrobial susceptibility of Proteus spp. causing APN in hospitalized children 


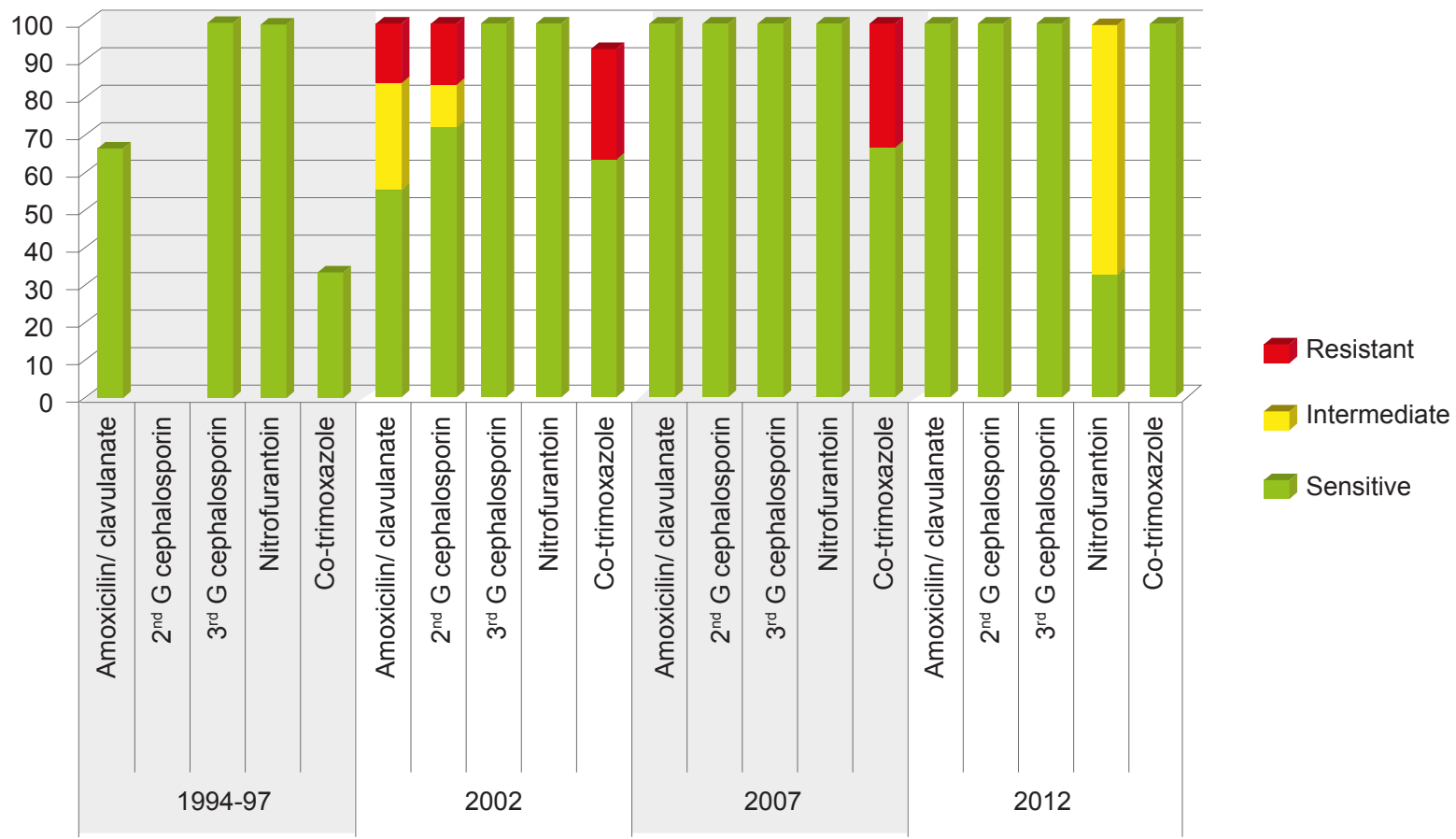

Figure 4 - In vitro antimicrobial susceptibility of Klebsiella spp. causing APN in hospitalized children

Empirical antibiotic therapy should be based on local antimicrobial sensitivity patterns, if available, and adjusted according to sensitivity testing of the isolated uropathogen. ${ }^{10}$ Other factors that should be taken into account are the age, the presence of underling conditions, renal function, previous episode of UTI, current antibiotic prophylaxis and oral tolerance. ${ }^{3}$ As frequent irrational use of antibiotics changes the intestinal flora, leading to bacterial resistance ${ }^{1}$, antibiotic for APN treatment should be selected based on resistance percentage of the main etiological agents, preferably under $10-20 \% .{ }^{3}$ And because increasing rates of resistance among bacterial uropathogens has caused growing concern in both developed and developing countries ${ }^{11}$ regular monitoring of resistance patterns is necessary to improve guidelines for empirical antibiotic therapy. ${ }^{12}$ In our study, sensitivity of Escherichia coli to amoxicillin-clavulanate, including intermediate sensitivity in vitro was around $100 \%$ with very low percentage regarding resistance. There were no cases of resistance to amoxicillin-clavulanate regarding Proteus spp. during the study period and Klebsiella spp since 2002.

There is a positive correlation between antimicrobial resistance and the consumption of antibiotics. ${ }^{13}$ In European countries, systemic antibiotics are prescribed in the greatest volumes to ambulatory patients, mostly for respiratory tract infections. ${ }^{14}$ Increasing awareness of antimicrobial resistance and promoting the rational use of antibiotics among prescribers and the general public are the key to combating the unnecessary use of these drugs and various initiatives have been implemented throughout Europe to support the prudent use of antimicrobials, including the Antibiotic Stewardship International projects..$^{15-21}$

In Portugal antibiotic management policies regarding resistance and costs have been changing during the last decades. ${ }^{22}$ The higher use of antibiotics in respiratory infections in Primary Care changed during the last decade..$^{23}$ In clinical practice should be target that in line with policies of rational use of drugs, mainly antibiotics, treatments should be based on maximum efficiency and lowest cost strategies.

During the study period the protocol used was the same and regular updates were performed according to the 'state of the art'. Regarding the criteria age for hospitalization included in the protocol it decreased over the time, fact that justifies the decreasing of median age in hospitalized children in our center during the study period.

\section{CONCLUSIONS}

UTI is one of the most common diseases in children. Early diagnosis and treatment can significantly decrease late serious complications. Knowledge of the sensitivity and resistance pattern of uropathogens in specific geographical locations is an important factor for choosing suitable antibacterial treatment.

Our results show an improvement in the profiles of sensitivity and resistance of antimicrobial agents used in APN treatment during the last 18 years. Amoxicillinclavulanate remains a good first-line choice for empirical treatment of APN in our inpatient care.

\section{ACKNOWLEDGMENTS}

To João Tiago Guimarães, Department of Biochemistry from Faculty of Medicine, University of Porto and Department of Clinical Pathology, Centro Hospitalar de São João, for the revision of the manuscript. 


\section{CONFLICTS OF INTEREST}

The authors declare that there is no conflict of interests regarding the publication of this article.

\section{REFERENCES}

1. Farshad S, Ranjbar $R$, Japoni A, Hosseini $M$, Anvarinejad $M$, Mohammadzadegan R. Microbial susceptibility, virulence factors, and plasmid profiles of uropathogenic Escherichia coli strains isolated from children in Jahrom Iran. Arch Iran Med. 2012;15:312-6.

2. Habib S. Highlights for management of a child with a urinary tract infection. Int J Pediatr. 2012;2012:943653.

3. de Lucas Collantes C, Cela Alvargonzalez J, Angulo Chacón AM, García Ascaso M, Piñeiro Pérez R, Cilleruelo Ortega MJ, et al. Infecciones de tracto urinario: sensibilidad antimicrobiana y seguimiento clínico. An Pediatr. 2012;76:224-8

4. Saadeh S, Mattoo TK. Managing urinary tract infections. Pediatr Nephrol. 2011;26:1967-76.

5. Macgowan A, Albur M. Frontline antibiotic therapy. Clin Med 2013;13:263-8.

6. Infectious Diseases Society of America (IDSA), Spellberg B, Blaser M Guidos RJ, Boucher HW, Bradley JS, et al. Combating antimicrobial resistance: policy recommendations to save lives. IDSA Policy Paper. 2011;52:S397-428.

7. Siomos M. EU research on antimicrobial resistance: EU projects 2007-2010. 2011. [Consulted 2013 September 30]. Available at: http:// ec.europa.eu/research/health/infectious-diseases/antimicrobial-drugresistance/pdf/eu-research-on-antimicrobial-resistance_en.pdf.

8. Direção Geral de Saúde. Diagnóstico e tratamento da infeção do trato urinário em idade pediátrica. 2012. [Consulted 2013 September 30]. Available at: http://www.dgs.pt/.

9. Sangrador C, Raposo M, Proyecto Gld. Tratamiento antibiótico recomendado en episodios de infección urinaria. An Pediatr. 2007:67:485-97.

10. Subcommittee on Urinary Tract Infection, Steering Committee on Quality Improvement and Management, Roberts KB. Urinary Tract Infection: Clinical Practice Guideline for the Diagnosis and Management of the Initial UTI in Febrile Infants and Children 2 to 24 Months. Pediatrics. 2011;28:595-610.

11. Guidoni E, Berezin E, Nigro S, Santiago N, Benini V, Toporovski J Antibiotic resistance patterns of pediatric community-acquired urinary infections. Braz J Infect Dis. 2008;12:321-23.

12. Farajnia S, Alikhani M, Ghotaslou R, Naghili B, Nakhlband A. Causative agents and antimicrobial susceptibilities of urinary tract infections in the northwest of Iran. Int J Infect Dis. 2009;13:140-44

13. Goossens H. Antibiotic consumption and link to resistance. Clin

\section{FUNDING SOURCES}

No subsidies or grants contributed to this work.

Microbiol Infect. 2009;15:12-5

14. Earnshaw S, Monnet DL, Duncan B, O'Toole J, Ekdahl K, Goossens H, et al. European antibiotic awareness day 2008: the first Europe-wide public information campaign on prudent antibiotic use; methods and survey activities in participating countries. Eurosurveillance. 2009;14:418-25.

15. Bruce J, MacKenzie FM, Cookson B, Mollison J, van der Meer JW, Krcmery $\mathrm{V}$, et al. Antibiotic stewardship and consumption: findings from a pan-European hospital study. J Antimicrob Chemother. 2009;64:85360.

16. Huttner B, Goossens H, Verheij T, Harbarth S; CHAMP consortium Characteristics and outcomes of public campaigns aimed at improving the use of antibiotics in outpatients in high-income countries. Lancet. 2010;10:17-31.

17. Molstad S, Cars O, Struwe J. Strama - a Swedish working model for containment of antibiotic resistance Eurosurveillance. 2008;13:22-5.

18. Gonzales R, Corbett KK, Wong S, Glazner JE, Deas A, Leeman-Castillo $B$, et al. Get smart Colorado: impact of a mass media campaign to improve community antibiotic use. Med Care. 2008;46:597-605.

19. Sabuncu E, David J, Bernède-Bauduin C, Pépin S, Leroy M, Boëlle PY, et al. Significant reduction of antibiotic use in the community after a nationwide campaign in France 2002-2007. PLoS Med. 2009;6:e:1000084.

20. Tacconelli E, De Angelis G. Fighting antibiotic resistance all over Europe. Expert Rev Anti Infect Ther. 2010;8:761-3.

21. ESAC Scientific Advisory Board, ESAC National Networks. European Surveillance of Antimicrobial Consumption. 2007. Antwerp: ESAC YearBook; 2006.

22. Ministério da Saúde - Direcção Geral de Saúde. Plano Nacional de Saúde Português 2004-2010. [Consulted 2013 September 09]. Available at: http://www.dgssaude.min-saude.pt/pns/.

23. Caldeira L, INFARMED. Caracterização da prescrição de antibióticos em infecções do tracto respiratório por parte dos médicos de clínica geral e da carreira de medicina geral e familiar do continente português. Lisboa: Observatório do Medicamento e dos Produtos de Saúde; 2002.

24. Carvalho F, Oliveira A, Afonso $C$, Jardim H. Análise dos agentes etiológicos de Pielonefrite guda e sua sensibilidade aos antimicrobianos. Acta Pediatr Port. 2000;31:359-62.

25. Pissarra S, Correia-Fonseca J, Jardim H. Sensibilidade aos antimicrobianos dos agentes de peilonefrite aguda. Acta Pediatr Port. 2006;3:87-90 
Filipa FLOR-DE-LIMA, Tânia MARTINS, Ana TEIXEIRA, Helena PINTO, Edgar BOTELHO-MONIZ, Alberto CALDAS-AFONSO

\section{Etiological Agents and Antimicrobial Susceptibility in Hospitalized Children with Acute Pyelonephritis}

Acta Med Port 2015:28:15-20

Publicado pela Acta Médica Portuguesa, a Revista Científica da Ordem dos Médicos

Av. Almirante Gago Coutinho, 151

1749-084 Lisboa, Portugal.

Tel: +351218428215

E-mail: submissao@actamedicaportuguesa.com

www.actamedicaportuguesa.com

ISSN:0870-399X | e-ISSN: 1646-0758

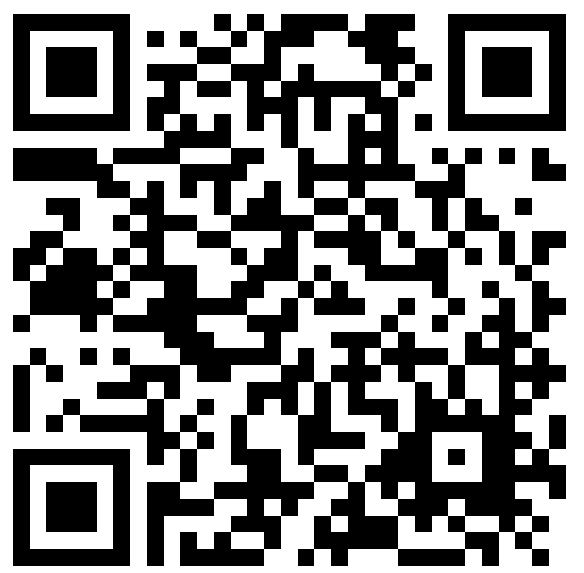

